Research Article

\title{
Effect of tianeptine on seizure threshold and anticonvulsant activity of valproate, phenobarbitone and phenytoin in mice
}

\author{
Ashok K. Sharma ${ }^{1}$, Navdeep Dahiya ${ }^{1}$, Amol Khanapure ${ }^{2}$, Jayant K. Kairi ${ }^{3}$
}

\begin{abstract}
${ }^{1}$ Department of Pharmacology, AFMC, Pune, Maharashtra, India

${ }^{2}$ Regional Medical Officer, 34 AR, C/O 99 APO

${ }^{3}$ Department of Pharmacology, ACMS, New Delhi, India
\end{abstract}

Received: 07 March 2016 Accepted: 08 April 2016

*Correspondence to:

Dr. Navdeep Dahiya,

Email: navdeepdahiya

@ rediffmail.com

Copyright: () the author(s), publisher and licensee Medip Academy. This is an openaccess article distributed under the terms of the Creative Commons Attribution NonCommercial License, which permits unrestricted noncommercial use, distribution, and reproduction in any medium, provided the original work is properly cited.

\begin{abstract}
Background: Depression is a common psychiatric comorbidity in patients with epilepsy and often remains untreated due to concern of antidepressant induced seizures. Tricyclic antidepressants, norepinephrine reuptake inhibitors and bupropion have been shown to increase the risk of seizures. Selective serotonin reuptake inhibitors and venlafaxine have shown both anticonvulsant and proconvulsant activity. The information on anticonvulsant effects of tianeptine, a newer antidepressant, is limited to few animal studies. In view of this, the present study was undertaken to investigate the anticonvulsant activity of tianeptine and its interaction with conventional antiepileptic drugs (AEDs) viz. valproate, phenobarbitone and phenytoin in mice.

Methods: The study was carried out in 3 phases using healthy adult male mice. In phase I, effect of oral administration of tianeptine on seizure threshold was studied using electroconvulsive threshold method. In phase II and phase III, effect of tianeptine on median effective dose $\left(\mathrm{ED}_{50}\right)$ of valproate, phenobarbitone and phenytoin was studied using maximal electroshock seizure (MES) test after administering tianeptine with these AEDs in various combinations. In phase II, drugs were administered orally once while in phase III, these were daily administered orally for 28 days.

Results: In phase I, tianeptine increased electroconvulsive threshold in dose dependent manner but effect was significant only at 20 and $40 \mathrm{mg} / \mathrm{kg} \quad(\mathrm{P}<0.05$ and 0.001 respectively). In phase II and III, tianeptine exhibited dose dependent reduction in $\mathrm{ED}_{50}$ of all the studied AEDs, however, significant reduction of $\mathrm{ED}_{50}$ of valproate and phenobarbitone $(\mathrm{P}<0.05$ for both) was observed only when tianeptine was administered at $40 \mathrm{mg} / \mathrm{kg}$, while significant reductions in $\mathrm{ED}_{50}$ of phenytoin were observed when tianeptine was administered as 20 and $40 \mathrm{mg} / \mathrm{kg}(\mathrm{P}<0.05$ and 0.01 respectively) and in phase III, significant reduction of $\mathrm{ED}_{50}$ value of valproate $(\mathrm{P}<0.01)$ and phenobarbitone $(\mathrm{P}<0.05)$ was observed with tianeptine at $40 \mathrm{mg} / \mathrm{kg}$ while reduction in $\mathrm{ED}_{50}$ of phenytoin was significant at all the studied doses of tianeptine with $\mathrm{P}<0.05$ at 10 and $20 \mathrm{mg} / \mathrm{kg}$ and $\mathrm{P}<0.01$ at $40 \mathrm{mg} / \mathrm{kg}$..

Conclusions: Tianeptine exhibits anticonvulsant action which is synergistic with anticonvulsant effects of valproate, phenobarbitone and phenytoin suggesting that tianeptine may be a safe option in patients of epilepsy concurrently suffering from depression.
\end{abstract}

Keywords: Tianeptine, Anticonvulsant, Antidepressant

\section{INTRODUCTION}

Depression is a common psychiatric comorbidity in patients with epilepsy and often remains untreated due to concern of antidepressant induced seizures. ${ }^{1-4}$
Tricyclic antidepressants, norepinephrine reuptake inhibitors and bupropion have been shown to increase risk of seizures. Selective serotonin reuptake inhibitors (SSRIs) are considered relatively safe however, escitalopram has been shown to increase seizure severity 
in an experimental study. ${ }^{5,6}$ Venlafaxine, a serotonin and noradrenaline reuptake inhibitor (SNRI) has also shown both anticonvulsant and proconvulsant activity in animal studies. $^{7-10}$

The information on anticonvulsant effects of tianeptine, a newer antidepressant, is limited to few animal studies and one retrospective clinical study stating that tianeptine does not influence the type of epileptic syndrome, baseline frequency and number of co-administered antiepileptic drugs (AEDs). ${ }^{11-15}$ In view of this, the present study was undertaken to investigate anticonvulsant activity of tianeptine and its interaction with conventional AEDs viz. valproate, phenobarbitone and phenytoin in mice.

\section{METHODS}

Healthy adult Swiss albino male mice, weighing 20-30 g, housed in sterile polypropylene cages containing sterile paddy husk as bedding material, on standard laboratory diet and water ad libitum, acclimatized to standardized laboratory conditions for 1 week before the start of the study were used in the study as per guidelines of committee for the purpose of control and supervision on experiments on animals (CPCSEA) after the approval from institutional animal ethics committee. ${ }^{16}$

The study was carried out in the 3 phases. In phase I, effect of tianeptine on the electroconvulsive threshold was studied. Animals were divided into 4 groups of 24 animals each and received the following treatments orally once: Group A: Tianeptine $10 \mathrm{mg} / \mathrm{kg}$, Group B: Tianeptine $20 \mathrm{mg} / \mathrm{kg}$, Group C: Tianeptine $40 \mathrm{mg} / \mathrm{kg}$ and Group D: Vehicle (1\% gum acacia). ${ }^{17}$ Each of these groups was further subdivided into 4 subgroups of 6 animals each and exposed to electroshocks of various intensities i.e. $6,8,10$ and $12 \mathrm{~mA}$ for 0.2 seconds. The number of animals exhibiting tonic extension of the hind limbs at an intensity of current in a group was noted and median current strength i.e. $\mathrm{CS}_{50}$ along with its standard error of mean (SEM) was calculated for various treatment groups and control group by the method of Miller and Tainter. ${ }^{18}$ The pattern of change in $\mathrm{CS}_{50}$ value in relation to tianeptine dose was observed and $\mathrm{CS}_{50}$ of individual treatment groups was compared with control group.

Table 1: Study design for phase II and phase III.

\begin{tabular}{|c|c|c|c|c|c|c|c|c|c|c|}
\hline \multirow{3}{*}{ Groups"' } & \multirow{3}{*}{$\begin{array}{l}\text { Dose of tianeptine used with } \\
\text { AED (mg/kg) }\end{array}$} & \multicolumn{9}{|c|}{ Number of animals and doses of AED used in various groups } \\
\hline & & \multicolumn{3}{|c|}{ Valproate $(\mathrm{mg} / \mathrm{kg})$} & \multicolumn{3}{|c|}{ Phenobarbitone $(\mathrm{mg} / \mathrm{kg})$} & \multicolumn{3}{|c|}{ Phenytoin $(\mathrm{mg} / \mathrm{kg})$} \\
\hline & & 100 & 200 & 400 & 5 & 10 & 20 & 5 & 10 & 20 \\
\hline Control & - & 6 & 6 & 6 & 6 & 6 & 6 & 6 & 6 & 6 \\
\hline I & 10 & 6 & 6 & 6 & 6 & 6 & 6 & 6 & 6 & 6 \\
\hline II & 20 & 6 & 6 & 6 & 6 & 6 & 6 & 6 & 6 & 6 \\
\hline III & 40 & 6 & 6 & 6 & 6 & 6 & 6 & 6 & 6 & 6 \\
\hline
\end{tabular}

Groups*' were added suffix 'A' for phase II and 'C' for phase III. Each group was further sub-grouped according to AED and its dose used.

In phase II, the acute effect of tianeptine on the median effective dose $\left(\mathrm{ED}_{50}\right)$ of $\mathrm{AEDs}$ viz. valproate, phenobarbitone and phenytoin was studied using maximal electroshock seizure (MES) test. ${ }^{11}$ For each AED a total of 9 groups of 6 mice each were used and administered tianeptine and AED in various dose combinations as single dose orally. The controls for each AED were formed by 3 groups of 6 animals each; each control subgroup received a different dose of AED only as drug treatment (Table 1). The animals were given maximal electroshock i.e. electrical stimulus of $48 \mathrm{~mA}$ for 0.2 seconds via auricular electrodes and the number of animals protected (exhibiting no tonic hind limb extension) against this shock was recorded for each group. $\mathrm{ED}_{50}$ values along with SEM were calculated for various groups by Miller and Tainter method. ${ }^{17}$ The pattern of change in $\mathrm{ED}_{50}$ value of each AED in relation to tianeptine dose was observed and $\mathrm{ED}_{50}$ of individual treatment groups was compared with control group.
Phase III was conducted to study chronic effect of tianeptine on $\mathrm{ED}_{50}$ of valproate, phenobarbitone and phenytoin using the same study design as in phase II and combinations of tianeptine with AEDs were administered daily by oral route for 28 days.

\section{Statistical analysis}

Statistical analysis of data was done using Graph Pad® Version 6, 32 bit for windows. $\mathrm{CS}_{50}$ and $\mathrm{ED}_{50}$ values of drug treated groups were compared with control group values using Student's test. The level of significance was set at $\mathrm{P}<0.05$.

\section{RESULTS}

In phase I, tianeptine increased electroconvulsive threshold at all the studied doses in dose dependent 
manner but it was statistically significant only at 20 and $40 \mathrm{mg} / \mathrm{kg}$ with $\mathrm{P}<0.05$ and 0.001 respectively (Table 2).

Table 2: Effect of acute treatment with tianeptine on the electroconvulsive threshold in mice.

\begin{tabular}{|lll|}
\hline Groups & \multicolumn{1}{c|}{ Treatment given } & \multicolumn{1}{c|}{ CS $_{50}(\mathrm{~mA})$} \\
\hline $\mathrm{A}$ & Tianeptine $10 \mathrm{mg} / \mathrm{kg}$ & $7.85 \pm 0.5$ \\
\hline $\mathrm{B}$ & Tianeptine $20 \mathrm{mg} / \mathrm{kg}$ & $9.23 \pm 0.66 *$ \\
\hline $\mathrm{C}$ & Tianeptine $40 \mathrm{mg} / \mathrm{kg}$ & $11.35 \pm 0.71 * * *$ \\
\hline $\mathrm{D}$ (Control) $\quad$ Vehicle & $6.82 \pm 0.44$ \\
\hline
\end{tabular}

Values are expressed as mean \pm standard error of mean (SEM); *: $\mathrm{P}<0.05, * *: \mathrm{P}<0.01$ and $* * *: \mathrm{P}<0.001$ in comparison to control.

In phase II, tianeptine reduced the $\mathrm{ED}_{50}$ of all studied AEDs in dose dependent manner. Significant reduction of
$\mathrm{ED}_{50}$ value of valproate and phenobarbitone $(\mathrm{P}<0.05$ for both) was observed only when tianeptine was administered at $40 \mathrm{mg} / \mathrm{kg}$ (Table 3). However, significant reduction in $\mathrm{ED}_{50}$ of phenytoin was observed when tianeptine was administered as 20 and $40 \mathrm{mg} / \mathrm{kg}(\mathrm{P}<0.05$ and 0.01 respectively) (Table 3 ).

In phase III also, tianeptine reduced the $\mathrm{ED}_{50}$ of all the studied AEDs in a dose dependent manner. Significant reduction of $\mathrm{ED}_{50}$ of valproate $(\mathrm{P}<0.01)$ and phenobarbitone $\quad(\mathrm{P}<0.05)$ was observed with administration of tianeptine at $40 \mathrm{mg} / \mathrm{kg}$ only. However, reduction in $\mathrm{ED}_{50}$ of phenytoin was observed at all the studied doses of tianeptine with $\mathrm{P}<0.05$ at 10 and 20 $\mathrm{mg} / \mathrm{kg}$ and $\mathrm{P}<0.01$ at $40 \mathrm{mg} / \mathrm{kg}$ (Table 4).

Table 3: Effect of acute treatment with tianeptine on anticonvulsant action of valproate, phenobarbitone and phenytoin against maximal electroshock-induced seizures in mice.

\begin{tabular}{|lllll|}
\hline \multirow{2}{*}{ Groups } & Treatment given along with AED & \multicolumn{3}{c|}{ ED $_{\text {50 }}$ (mg/kg) } \\
\cline { 3 - 5 } Control & Vehicle & Valproate & Phenobarbitone & Phenytoin \\
\hline IA & Tianeptine $10 \mathrm{mg} / \mathrm{kg}$ & $237 \pm 18.40$ & $13.19 \pm 1.72$ & $12.74 \pm 1.56$ \\
\hline IIA & Tianeptine $20 \mathrm{mg} / \mathrm{kg}$ & $237 \pm 18.40$ & $13.19 \pm 1.59$ & $10.59 \pm 1.40$ \\
\hline IIIA & Tianeptine $40 \mathrm{mg} / \mathrm{kg}$ & $171.76 \pm 20.26 *$ & $7.25 \pm 1.43 *$ & $6.04 \pm 1.06 *$ \\
\hline
\end{tabular}

Values are expressed as mean \pm standard error of mean (SEM). *: $\mathrm{P}<0.05$ and **: $\mathrm{P}<0.01$ in comparison to control.

Table 4: Effect of chronic treatment with tianeptine on anticonvulsant action of valproate, phenobarbitone and phenytoin against maximal electroshock-induced seizures in mice.

\begin{tabular}{|c|c|c|c|c|}
\hline \multirow{2}{*}{ Groups } & \multirow{2}{*}{ Treatment given along with AED } & \multicolumn{3}{|l|}{$\mathrm{ED}_{50}(\mathrm{mg} / \mathrm{kg})$} \\
\hline & & Valproate & Phenobarbitone & Phenytoin \\
\hline Control & Vehicle & $237 \pm 18.40$ & $13.19 \pm 1.72$ & $12.74 \pm 1.56$ \\
\hline $\mathrm{IC}$ & Tianeptine $10 \mathrm{mg} / \mathrm{kg}$ & $237 \pm 18.40$ & $10.97 \pm 1.19$ & $8.42 \pm 0.66 *$ \\
\hline IIC & Tianeptine $20 \mathrm{mg} / \mathrm{kg}$ & $206.48 \pm 11.21$ & $8.32 \pm 1.41$ & $8.04 \pm 1.13 *$ \\
\hline IIIC & Tianeptine $40 \mathrm{mg} / \mathrm{kg}$ & $163.99 \pm 12.77 * *$ & $6.92 \pm 1.32 *$ & $5.56 \pm 0.67 * *$ \\
\hline
\end{tabular}

Values are expressed as mean \pm standard error of mean (SEM). *: $\mathrm{P}<0.05$ and **: $\mathrm{P}<0.01$ in comparison to control.

\section{DISCUSSION}

This study confirms that tianeptine exhibits inhibitory effects on seizure activity as reported in earlier studies and enhances the anticonvulsant effects of valproate and phenobarbitone as reported by Borowicz et al, however, contrary to Borowicz et al, anticonvulsant activity of phenytoin was also enhanced in this study on acute as well as chronic administration of tianeptine. ${ }^{11-14}$

Tianeptine structurally resembles tricyclic antidepressants but has different pharmacological properties. It selectively enhances presynaptic 5-HT uptake. In addition, it also increases mesolimbic release of dopamine and has additional anxiolytic, cytoprotective and procognitive effects. ${ }^{11}$ Tianeptine may be exhibiting its anticonvulsant effect through endogenous adenosine via adenosine A1 receptors. Uzbay TI et al. showed that tianeptine significantly delayed the onset time of pentylenetetrazole induced first myoclonic jerk (FMJ) and generalized clonic seizures in mice and the effects on FMJ were blocked by 8-cyclopentyl-1,3-dipropylxanthine, a selective adenosine A1 receptor antagonist. ${ }^{12}$ Adenosine A1 receptors exert their anticonvulsant activity by (a) inducing presynaptic inhibition as a result of reduction of inward flow of calcium ions and (b) reducing the excitability of the postsynaptic membrane by enhancing postsynaptic outflow of potassium through G-protein coupled inwardly rectifying potassium channels. ${ }^{19}$ 
Prevention of stress induced increase in NMDA mediated currents in rat amygdala and cornus ammonis area 3 hippocampal region and changes in expression of glutamate transporter EAAT2 (excitatory amino acid transporter 2, GLT1) by tianeptine in mice, suggest normalization of glutamatergic tone in brain as another mechanism for its anticonvulsant effects. ${ }^{11,20}$

Presence of high number of neuronal nitric oxide synthase (nNOS) positive neurons in neocortex of patients with long seizure history, induction of nNOS in cerebral cortex neurones after seizures and report of Wegener et al that local administration of tianeptine significantly decreased the hippocampal NOS activity in vivo propose inhibitory effect on NOS by tianeptine as another possible contributor to its anticonvulsant activity. ${ }^{21-23}$

Altered dopamine D1 and D2-like receptors signalling has been held responsible for epileptogenesis. Repeated administration of tianeptine has been documented to increase the functional responsiveness of dopamine D2/D3 receptors and extracellular concentration of dopamine in nucleus accumbens and striatum of rat brain. $^{25,26}$ The modulation of dopaminergic neurotransmission by tianeptine may also be another mechanism for its anticonvulsant effect.

Though serum or brain concentrations of tianeptine and AEDs have not been studied in this study but Borowicz et al have reported no change in brain concentration of valproate, phenytoin and a decrease in brain concentration of phenobarbitone with acute and chronic treatment of tianeptine $(25-50 \mathrm{mg} / \mathrm{kg})$ in mice suggesting that pharmacodynamic changes primarily contribute to the anticonvulsant effect of tianeptine. ${ }^{11}$

\section{CONCLUSIONS}

Tianeptine possesses anticonvulsant action which is synergistic with valproate, phenobarbitone and phenytoin suggesting that tianeptine may be given safely in patients of epilepsy concurrently suffering from depression. However, since the study is experimental in nature and there is only one retrospective clinical study suggesting that tianeptine when administered in epileptic patients does not exacerbate the epilepsy, the findings need to be further confirmed in more number of clinical studies before such an approach is applied clinically.

\section{Funding: No funding sources}

Conflict of interest: None declared

Ethical approval: The study was approved by the Institutional Ethics Committee

\section{REFERENCES}

1. Jackson MJ, Turkington D. Depression and anxiety in epilepsy. J Neurol Neurosurg Psychiatry. 2005;76(1):45-7.
2. Cardamone L, Salzberg MR, O'Brien TJ, Jones NC. Antidepressant therapy in epilepsy: can treating the comorbidities affect the underlying disorder? $\mathrm{Br} \mathrm{J}$ Pharmacol. 2013;168:1531-54.

3. Dailey JW, Naritoku DK. Antidepressants and seizures: clinical anecdotes overshadow neuroscience. Biochem Pharmacol. 1996;52(9):1323-9.

4. Pisani F, Spina E, Oteri G. Antidepressant drugs and seizure susceptibility: from in vitro data to clinical practice. Epilepsia. 1999;40(10):48-56.

5. O'Donnel JM, Shelton RC. Drug therapy of depression and anxiety disorders. In: Brunton LL, Chabner BA, Knollmann BC, editors. Goodman and Gilman's The Pharmacological Basis of Therapeutics. $12^{\text {th }}$ ed. New York: McGraw Hill; 2011:397-415.

6. Kamal SM. Effect of escitalopram and venlafaxine on seizure score and lipid peroxidation in mice receiving carbamazepine antiepileptic therapy. J Egypt Soc Toxicol. 2007;36:1-6.

7. Gokul CG, Santosh R, Abhishek A, Prabhakar A, Naveen KM, Reshma SR. A study on effect of trazadone, amoxapine and venlafaxine on MES (maximal electroshock) induced seizures in albino rats. Pharmacologyonline. 2011;3:214-21.

8. Borowicz KK, Gołyska D, Luszczki JJ, Czuczwar SJ. Effect of acutely and chronically administered venlafaxine on the anticonvulsant action of classical antiepileptic drugs in the mouse maximal electroshock model. Eur J Pharmacol. 2011;670(1):114-20.

9. Aricioglu F, Salanturoglu G, Buldanlioglu U, Ozyalcin S. Effect of venlafaxine on maximal electroshock induced seizures in mice. Ann Gen Psychiatry. 2006;5(1):1.

10. Santos JG, Do Monte FHM, Russi M, Agustine PE, Lanziotti VMNB. Proconvulsant effects of high doses of venlafaxine in pentylenetetrazole-convulsive rats. Braz J Med Biol Res. 2002;35(4):469-72.

11. Borowicz KK, Banach M, Piskorska B, Czuczwar SJ. Effect of acute and chronic tianeptine on the action of classical antiepileptics in the mouse maximal electroshock model. Pharmacol Rep. 2013;65(2):379-88.

12. Uzbay TI, Kayir H, Ceyhan M. Effects of tianeptine on onset time of pentylenetetrazole-induced seizures in mice: possible role of adenosine A1 receptors. Neuropsychopharmacology. 2007;32(2):412-6.

13. Uzbay T, Kayir H, Celik T, Yüksel N. Acute and chronic tianeptine treatments attenuate ethanol withdrawal syndrome in rats. Prog Neuropsychopharmacol Biol Psychiatry. 2006;30(3):478-85.

14. Ceyhan M, Kayir H, Uzbay IT. Investigation of the effects of tianeptine and fluoxetine on pentylenetetrazole-induced seizures in rats. $\mathrm{J}$ Psychiatr Res. 2005;39(2):191-6. 
15. Moon J, Jung KH, Shin JW, Lim JA, Byun JI, Lee ST, et al. Safety of tianeptine use in patients with epilepsy. Epilepsy Behav. 2014;34:116-9.

16. CPCSEA guidelines for laboratory animal facility. Indian J Pharmacol. 2003;35(13):257-74.

17. Luszczki JJ, Swiader M, Parada-Turska J, Czuczwar SJ. Tiagabine synergistically interacts with gabapentin in the electroconvulsive threshold test in mice. Neuropsychopharmacology. 2003;28:1817-30.

18. Randhawa MA. Calculation of $\mathrm{LD}_{50}$ values from the method of Miller and Tainter, 1944. J Ayub Med Coll Abbottabad. 2009;21(3):184-5.

19. Boison D. Adenosine dysfunction in epilepsy. Glia. 2012;60(8):1234-43.

20. Yilmaz I, Sezer Z, Kayir H, Uzbay TI. Mirtazapine does not affect pentylenetetrazole- and maximal electroconvulsive shock-induced seizures in mice. Epilepsy Behav. 2007;11:1-5.

21. Hernández TG, Marín VG, Delgado MP, González MG, Torres NR. Nitric oxide synthase expression in the cerebral cortex of patients with epilepsy. Epilepsia. 2000;41(10):1259-68.
22. Huh Y, Heo K, Park C, Ahn H. Transient induction of neuronal nitric oxide synthase in neurons of rat cerebral cortex after status epilepticus. Neurosci Lett. 2000;281(1):49-52.

23. Wegener G, Volke V, Harvey BH, Rosenberg R. Local, but not systemic, administration of serotonergic antidepressants decreases hippocampal nitric oxide synthase activity. Brain Res. 2003;959(1):128-34.

24. Bozzi Y, Borrelli E. The role of dopamine signaling in epileptogenesis. Front Cell Neurosci. 2013;7:1-12.

25. Wasylewska MD, Rogoz Z, Skuza G, Dlaboga D, Maj J. Effect of repeated treatment with tianeptine and fluoxetine on central dopamine $\mathrm{D}(2) / \mathrm{D}(3)$ receptors. Behav Pharmacol. 2002;13(2):127-38.

26. Invernizzi R, Pozzi L, Garattini S, Samanin R. Tianeptine increases the extracellular concentrations of dopamine in the nucleus accumbens by a serotonin-independent mechanism. Neuropharmacology. 1992;31(3):221-7.

Cite this article as: Sharma AK, Dahiya N, Khanapure A, Kairi JK. Effect of tianeptine on seizure threshold and anticonvulsant activity of valproate, phenobarbitone and phenytoin in mice. Int J Basic Clin Pharmacol 2016;5:850-4. 